Researchartide

\title{
AGING IMPAIRS ENDOCYTIC CAPACITY OF SPLENIC DENDRITIC CELLS FROM DARK AGOUTI RATS AND ALTERS THEIR RESPONSE TO TLR4 STIMULATION
}

\author{
BUFAN Biljana ${ }^{1}$, STOJIĆ-VUKANIĆ Zorica ${ }^{1}$, DJIKIĆ Jasmina ${ }^{2}$, KOSEC Duško ${ }^{3}$, \\ PILIPOVIĆ Ivan ${ }^{3}$, NACKA-ALEKSIĆ Mirjana ${ }^{2}$, ARSENOVIĆ-RANIN Nevena ${ }^{1}$ \\ LEPOSAVIĆ Gordana ${ }^{2 *}$
}

\begin{abstract}
${ }^{1}$ Department of Microbiology and Immunology, University of Belgrade-Faculty of Pharmacy, Belgrade, Serbia; ${ }^{2}$ Department of Physiology, University of Belgrade-Faculty of Pharmacy, Belgrade, Serbia; ${ }^{3}$ Immunology Research Centre "Branislav Janković", Institute of Virology, Vaccines and Sera "Torlak", Belgrade, Serbia
\end{abstract}

(Received $9^{\text {th }}$ June; Accepted $22^{\text {nd }}$ December 2014)

The study was undertaken considering: i) that relative proportion of distinct subsets of splenic dendritic cells (DCs) is strain-specific and predictive for the susceptibility to autoimmune diseases; ii) age-related changes in endocytic, allostimulatory and polarizing capacity of splenic OX62+ DCs from Albino Oxford rats (relatively resistant to Th1/Th17-mediated diseases) and iii) strain specificities in age-related changes of mouse DCs. To ascertain whether there are strain specificities in age-related rat DC changes, we examined the influence of aging on OX62+ DCs from Dark Agouti (DA) rats prone to Th1/Th17-mediated autoimmune diseases. The study provided additional evidence that the predominance of CD4- cells within OX62+ DCs from young adult rats correlates with their susceptibility to Th1/Th17-mediated diseases. Consistently, lipopolysaccharide (LPS)-matured DCs from 3-month-old (young) rats exhibited Th1 driving force when co-cultured with allogeneic CD4+ T cells. This most likely reflected enhanced TNF- $\alpha$ and iNOS expression. Comparing with young rats, OX62+ DCs from 26-month-old (aged) rats showed: i) diminished endocytic capacity; ii) impaired ability to mature invitroupon LPS stimulation (as indicated by lower MHC II, CD86 and CD40 surface expression), which is consistent with the increase in their IL-10 production, and iii) diminished allostimulatory capacity and loss of Th1-driving capacity in the mixed lymphocyte reaction. The latter, probably, reflected greater IL-10 production by LPSstimulated DC from aged rats, as well as lower CD40 density on their surface. Overall, our findings suggest that aging might affect DA rat capability to mount an efficient Th1 immune response, and consequently susceptibility to Th1/Th17-mediated pathology.

Key words: aging, allostimulatory capacity, splenic conventional dendritic cells, strain differences, Th polarization

Corresponding author: e-mail: Gordana.Leposavic@pharmacy.bg.ac.rs 


\section{INTRODUCTION}

Dendritic cells (DCs) are highly specialized antigen-presenting cells that integrate a variety of incoming signals and orchestrate the immune response [1]. Upon encountering antigens in the presence of inflammation and danger signals these cells mature (up-regulate $\mathrm{MHC}$ and co-stimulatory molecules) and present antigen to naïve T lymphocytes. Naïve T lymphocytes require two signals to become fully activated. A first signal, which is antigen-specific, is provided through the $\mathrm{T}$ cell receptor (TCR) which interacts with peptide-MHC molecules on the membrane of DCs. A second signal, the co-stimulatory signal, is antigen nonspecific and is provided by the interaction between co-stimulatory molecules expressed on the membrane of DCs (CD80, CD86) and CD28 on T cells. In addition, DCs, through the production of various cytokines, play a decisive role in the differentiation/polarization of activated $\mathrm{T}$ cells into Th1, Th2, Th17 or Treg effector cells [2].

DCs represent a heterogeneous cell population. This population can be divided into subsets that differ in morphological, phenotypic and functional characteristics. In the rat spleen, can be distinguished, at least, three morphologically and phenotypically distinct DC subsets: two (CD4+ and CD4-) conventional subsets, which express the $\alpha_{\text {OX-62 }}$ integrin subunit (CD103) recognized by the monoclonal antibody (mAb) MRC OX62 (OX62+ DCs), and a plasmacytoid subset [3,4]. Conventional CD4- DCs (OX62+CD11b+MHC II+CD4-) have a myeloid-related morphology, produce large amounts of the proinflammatory cytokines, and induce a Th1 response in allogeneic CD4+ $\mathrm{T}$ cells [3]. On the other hand, the CD4+ DCs (OX62+CD11b+MHC $\mathrm{II}+\mathrm{CD} 4+$ ) display a more heterogeneous morphology than CD4- DCs and they are shown to be: i) strong inducers of CD4+ and CD8+ T cell proliferation, ii) very poor producers of inflammatory cytokines and iii) capable to induce both Th1 and Th2 responses [3]. Rat splenic plasmacytoid DCs, having an undifferentiated morphology, do not express the OX62 marker (OX62-CD11b-MHC II+CD4+CD45R+) and after stimulation of Toll-like receptor (TLR) 7 and 9 produce large amounts of type I IFN [4].

Aging is associated with a progressive decline in immune function (immunosenescence) resulting in augmented susceptibility to viral and bacterial infections, decreased response to vaccines and, increased incidence of cancer and altered incidence of many autoimmune diseases [5,6,7]. Although deleterious effects of aging on immune responsiveness have mainly been attributed to alterations in the T-lymphocyte compartment [8,9], age-associated perturbations in the DC pool from mice and humans have been also indicated [10-16]. The data on the influence of aging on rat DCs are rather limited. Our recent study [17] described the influence of aging on DCs from Albino Oxford (AO) rats, which are relatively resistant to several Th1/Th17mediated autoimmune diseases [18,19]. More specifically, this study demonstrated the predominance of CD4+ cells in fresh suspensions of splenic OX62+ DCs from young AO rats, and an age-related shift in CD4+:CD4- subset ratio towards the CD4- 
cells producing large amounts of the proinflammatory cytokines [20]. It should be pointed that in the rat the relative proportion of distinct splenic DC subsets is straindependent $[18,20]$ and highly predictive for strain-dependent susceptibility to organspecific autoimmune diseases [20]. In this context it is important to add that in vitro LPS-activated splenic OX62+ DCs from aged AO rats express more TNF- $\alpha$, IL-12, IL-6 and IL-23 and exhibit an enhanced Th1/Th17 driving capacity when compared with the corresponding cells from young rats [17]. In keeping with the latter findings, aged $\mathrm{AO}$ rats exhibit an increased susceptibility to the induction of experimental autoimmune encephalomyelitis (EAE), a prototype of Th1/Th17 autoimmune disease, when compared to the young ones [17].

Furthermore, the study in mice revealed that aging differentially affects DCs from the prototypical Th1 strain C57BL/6 and the prototypical Th2 strain BALB/c [21]. However, there is no data on the putative influence of strain on age-related alterations in rat DCs.

Having all the aforementioned in mind, this study was designed to explore: (i) the relative proportion of distinct cell subsets within freshly isolated splenic conventional OX62+ DCs (the main antigen presenting cells of the immune system) from young Th1/Th17-mediated organ-specific autoimmune disease prone Dark Agouti (DA) rats $[19,22,23]$, their phenotypic characteristics and endocytic capacity, as well as their cytokine secretory profile, allostimulatory and polarizing capacity following in vitro maturation with LPS and (ii) the influence of aging on these phenotypic and functional parameters. For this purpose, we examined splenic OX62+ DCs from 3-month-old (young) and 26-month-old (aged) rats.

\section{MATERIALAND METHODS}

\section{Animals}

In the present study, we used 3- and 26-month-old female DA rats bred in the animal facility of the Immunology Research Centre „Branislav Janković“ at the Institute of Virology, Vaccines and Sera "Torlak", Belgrade, Serbia. All rats were euthanized by exposure to increasing doses of $\mathrm{CO}_{2}$ and spleens were carefully dissected. Only clinically healthy animals were used in this study. The animals showing evident signs of illness, tumors or splenomegaly at autopsy were not included in the study. The animals were handled in accordance with the Directive 2010/63/EU of the European Parliament and of the Council on the protection of animals used for scientific purposes (revising Directive 86/609/EEC). The experimental protocol was approved by the Experimental Animal Committee of the University of Belgrade-Faculty of Pharmacy, Belgrade, Serbia (No 6/12). 


\section{Reagents and antibodies}

In all cell cultures, RPMI 1640 medium (Sigma-Aldrich Chemie GmbH, Taufkirchen, Germany) supplemented with $2 \mathrm{mM}$ L-glutamine (Serva, Heidelberg, Germany), 1 $\mathrm{mM}$ sodium pyruvate (Serva), 100 units/ml penicillin (ICN, Costa Mesa, CA, USA), $100 \mu \mathrm{g} / \mathrm{ml}$ streptomycin (ICN) and 10\% fetal calf serum (FCS) (Gibco, Grand Island, NY, USA) were used. Collagenase D was obtained from Roche Diagnostics (Meylan, France). The density gradient mediums Optiprep ${ }^{\mathrm{TM}}$ and Percoll $^{\circledR}$, 4-(2-hydroxyethyl)1-piperazineethanesulfonic acid (HEPES), lipopolysaccharide from Escherihia di 0111:B4 (LPS), fluorescein-isothiocyanate (FITC)-conjugated dextran, 7-aminoactinomicin D (7-AAD), 5(6)-carboxyfluorescein diacetate succinimidyl ester (CFSE) and sodium azide were purchased from Sigma Aldrich Chemie GmbH. Ethylenediamine-tetraacetic acid (EDTA) and bovine serum albumin (BSA) were obtained from Fluka AG (Chemie) GmbH (Buchs SG, Switzerland).

In addition, we used the following mouse anti-rat mAbs: FITC/Phycoerithrin (PE)conjugated anti-CD4 (clone OX-38), peridinin chlorophyll protein (PerCP)-conjugated anti-TCR $\alpha \beta$ (clone R73), FITC/biotin-conjugated anti-CD11b (clone WT.5), biotinconjugated anti-CD80 (clone 3H5), FITC-conjugated anti-RT1B (MHC II, clone OX-6), biotin-conjugated anti-CD86 (clone 24F) and FITC-conjugated anti-CD40 (clone HM40-3). All these mAbs were purchased from BD Biosciences Pharmingen (San Diego, CA, USA). In addition, PE-conjugated anti- $\alpha_{\text {Ox-62 }}$ integrin subunit (anti-OX62; clone OX-62; AbD Serotec Oxford, UK) and rabbit anti-TLR4 Ab (Abcam, Cambridge, UK) were used. The FITC-conjugated goat-anti rabbit Ab and streptavidin-PerCP from BD Biosciences Pharmingen were used as secondary step Ab and reagent, respectively. The appropriate isotype controls were also purchased from BD Biosciences Pharmingen.

\section{DC isolation and stimulation}

As previously described in details [17], spleens were minced and digested in $2 \mathrm{mg} /$ $\mathrm{ml}$ collagenase $\mathrm{D}$ in RPMI $/ 2 \%$ FCS for $30 \mathrm{~min}$ at $37^{\circ} \mathrm{C}$. After washing in PBS $/ 2 \%$ FCS, cells were resuspended in RPMI/0.04\% EDTA and mixed with Optiprep ${ }^{\mathrm{TM}}(3: 1$ $\mathrm{v} / \mathrm{v})$ to give a $15 \%$ solution $(\varrho=1.085 \mathrm{~g} / \mathrm{ml})$. This cell suspension $(4 \mathrm{ml})$ was overlaid with $5 \mathrm{ml}$ of $11.5 \%$ Optiprep $^{\text {тм }}(\varrho=1.068 \mathrm{~g} / \mathrm{ml})$ and $2 \mathrm{ml} \mathrm{RPMI} / 0.02 \%$ EDTA and centrifuged at $600 \mathrm{~g}$ for $15 \mathrm{~min}$ at $4^{\circ} \mathrm{C}$. The low density cell fraction (LDF) at the interface of the top two layers was collected and washed.

Next, OX62+ cells were separated from splenic LDF using immunomagnetic cell separation technique and anti-rat OX62 microbeads (Miltenyi Biotec, Teterow, Germany). The separation procedure was conducted according to manufacturer`s instructions (Miltenyi Biotec). Briefly, after incubation of LDF with anti-rat OX62 microbeads $\left(4^{\circ} \mathrm{C}, 15 \mathrm{~min}\right)$, positive selection was performed on magnetic cell separation column by using QuadroMACS magnet (Miltenyi Biotec). The purity of DCs obtained in this manner was up to $85 \%$ (as shown by staining with FITC-CD11b). 
Next, magnetically sorted OX62+ cells were cultured in $24-$ well plates $\left(1 \times 10^{6}\right.$ cells $/ \mathrm{ml}$ per well) in the RPMI $/ 10 \%$ FCS with LPS $(1 \mu \mathrm{g} / \mathrm{ml})$ or without LPS (controls). After 16-18 h cells were collected and used for phenotypic and functional analyses, whereas supernatants were stored at $-70^{\circ} \mathrm{C}$ for cytokine assays.

\section{Mixed lymphocyte reaction}

The ability of OX62+ DCs to stimulate allogeneic CD4+ T cells was determined in MLR. Graded numbers (from $0.25 \times 10^{4}$ to $2 \times 10^{4}$ ) of control (non-stimulated) and LPS-stimulated OX62+ DCs were cultured in 96-well round-bottom plates with $1 \times 10^{5}$ CFSE-labeled CD4+ allogeneic T cells for 5 days. Allogeneic CD4+ T cells were isolated and purified from the spleen of young adult AO rats by Percoll gradient followed by the immunomagnetic cell separation technique with anti-CD4 microbeads (Miltenyi Biotec) according to manufacturer's instructions. Prior to culture, purified CD4+ T cells were labeled with CFSE. For labelling with CFSE, CD4+T cells were resuspended in PBS $\left(1 \times 10^{6}\right.$ cells $\left./ \mathrm{ml}\right)$ and incubated with $5 \mu \mathrm{M}$ CFSE for $10 \mathrm{~min}$ at $37^{\circ} \mathrm{C}$ in the dark. Then $5 \mathrm{x}$ the staining volume of ice-cold PBS $+5 \%$ FCS were added. Cells were incubated for $5 \mathrm{~min}$ on ice, and then washed before use. After a five-day-incubation, co-culture supernatants were collected and stored at $-70^{\circ} \mathrm{C}$ for cytokine assays.

\section{Fow cytometry analysis (FCA)}

Cells were examined using a FACScan flow cytometer (Becton Dickinson, Mountain View, CA, USA) and post-acquisition data analysis was performed with FlowJo software, v.7.8. (Three Star, Inc., Ashland, OR, USA).

\section{Analysis of surface markers}

For FCA, cells $\left(1 \times 10^{5}\right.$ cells per sample) were incubated with fluorochrome-labeled $\mathrm{mAb}$ (direct labeling) or with unlabeled Abs (indirect labeling) for $30 \mathrm{~min}$. Cells subjected to indirect labeling were incubated with the appropriate second step reagent for additional $30 \mathrm{~min}$. All incubations were performed in the dark on ice. After incubations cells were washed three times with $\mathrm{PBS} / 2 \% \mathrm{FCS} / 0.1 \%$ sodium azide. Non-specific isotype-matched controls were used for each fluorochrome type to define background staining, while dead cells and debris were excluded from analysis by selective gating based on anterior and right-angle scatter. The percentage of positive cells and mean fluorescence intensity (MFI), as the measure of average cell density of antigen expression, were determined for each labeling.

\section{Cell sunvival}

To estimate survival of OX62+ DCs and their subsets invitro 7-AAD, a fluorescent dye with strong affinity for DNA, was used. Following CD11b and CD4 immunolabelling, the cells were incubated with $5 \mu \mathrm{L}$ of $7-\mathrm{AAD}$ at $4^{\circ} \mathrm{C}$ for $20 \mathrm{~min}$, and subsequently 
examined for the proportion of apoptotic cells, i.e. cells exhibiting altered morphology (lower FSC and higher SSC) and increased 7-AAD incorporation (7-AAD+ cells).

\section{Measurement of RTC-dextran uptake}

To measure FITC-dextran uptake ability, freshly isolated OX62+ DCs $\left(1 \times 10^{5}\right.$ cells $)$ were incubated at $37^{\circ} \mathrm{C}$ or $4^{\circ} \mathrm{C}$ (negative control) in a media containing $1 \mathrm{mg} / \mathrm{ml}$ FITC-dextran for $90 \mathrm{~min}$. After incubation, the cells were washed twice with ice-cold $\mathrm{PBS} / 2 \% \mathrm{FCS} / 0.1 \%$ sodium azide to remove excess dextran. Percentage of dextran positive cells and MFI, resulting from the subtraction of the negative control from each experimental sample, represented the amount of incorporated tracer (FITCdextran).

\section{Analysis of allogeneic CD4+Tcell proliferation}

After 5 days of co-culturing with control and LPS-stimulated OX62+ DCs, CD4+ cells were immunolabeled for TCR $\alpha \beta$ expression, and CD4+TCR $\alpha \beta+$ cells were analyzed for proliferation by determining the division index and the proportion of cells with diminished amount of CFSE. The division index (the average number of divisions that a cell has undergone) was determined within the TCR $\alpha \beta+$ gate using the FlowJo proliferation platform. It is noteworthy that there is a positive correlation between the division index of cells and $\left[{ }^{3} \mathrm{H}\right]$ thymidine incorporation [24].

\section{Cytokine expression atmRNA and protein levels}

\section{Real-time PCR}

Total RNA was isolated from $1 \times 10^{5}$ freshly isolated and cultured OX62+ DCs by using the ABI Prism 6100 Nucleic Acid PrepStation (Applied Biosystems, Foster City, CA, USA) and Total RNA Chemistry (Applied Biosystems). Reverse transcription was performed with High Capacity cDNA Reverse Transcription Kit (Applied Biosystems), and $5 \mu$ l of cDNA was used for real-time PCR. Triplicate 25 $\mu \mathrm{l}$ reactions were ran under Applied Biosystems 7500 universal cycling conditions. Gene Expression Master Mix and commercial TaqMan Gene Expression Assays for rat IL-10 (Rn00563409_m1), TNF- $\alpha$ (Rn99999017_m1), IL-12a (Rn00584538_m1), IL-23a (Rn00590334_g1), IL-6 (Rn99999011_m1), TGF-ß1 (Rn00572010_m1), IL$1 \beta$ (Rn99999009_m1), TLR4 (Rn00569848_m1), NOS2 (Rn00561646_m1) and hypoxanthine phosphoribosyltransferase 1 (HPRT 1) (Rn01527840_m1) were obtained from Applied Biosystems. All procedures were performed according to manufacturer's instructions. Input cDNA was normalized to housekeeping gene (HPRT 1) as it displayed an optimal stability among various samples tested. Quantitative differences in gene expression levels were assessed using Applied Biosystems SDS software (v 1.4.0.) and $2^{-\Delta \Delta C t}$ method. 


\section{EUSA}

The concentration of TNF- $\alpha$, IL-12p70, IL-23, IL-6, IL-1 $\beta$ and IL-10 in supernatants from OX62+ DC cultures and IFN- $\gamma$, IL-17, IL-4, and IL-10 in supernatants from OX62+ DC:CD4+ T-cell co-cultures were measured by ELISA. We used the ELISA kits: rat IL-10 (R\&D Systems, Minneapolis, USA), rat IL-1 $\beta$ (Thermo Scientific, Rockford, IL, USA), rat IL-12p70 (Invitrogen Corporation, Camarillo, CA, USA), rat TNF- $\alpha$, IL-6 and IL-17A (Biolegend, San Diego, CA, USA), rat IL-4 (Bender Medsystems, Vienna, Austria), rat IL-23 (USCN Life Science Inc. Houston, USA). The tests were performed according to manufacturer's instructions. For IFN- $\gamma$ measurement a sandwich ELISA was used. Anti-rat IFN- $\gamma$ (clone DB1), biotinconjugated anti-rat IFN- $\gamma$ (polyclonal) and recombinant rat IFN- $\gamma$ were purchased from eBioscience, Vienna, Austria, whereas extravidin-peroxidase was purchased from Sigma Aldrich Chemie GmbH. A standard curve was generated with each assay with the limit of detection for TNF- $\alpha=2 \mathrm{pg} / \mathrm{ml}, \mathrm{IL}-12 \mathrm{p} 70<2.5 \mathrm{pg} / \mathrm{ml}, \mathrm{IL}-23=5.8 \mathrm{pg} /$ $\mathrm{ml}$, IL-6 $=5.3 \mathrm{pg} / \mathrm{ml}, \mathrm{IL}-10<10 \mathrm{pg} / \mathrm{ml}, \mathrm{IFN}-\gamma=5.6 \mathrm{pg} / \mathrm{ml}, \mathrm{IL}-17=8 \mathrm{pg} / \mathrm{ml}$, IL-4 $=0.2 \mathrm{pg} / \mathrm{ml}$ and IL $-1 \beta<5 \mathrm{pg} / \mathrm{ml}$.

\section{Statistical analysis}

Data are presented as means \pm SEM of the values. To assess significance of differences between groups, we used the following statistical tests: two-way ANOVA followed by Bonferroni test for post hoc comparisons (for testing the influence of aging and culturing), two-way Kruskal-Wallis test followed by Mann-Whitney U test for post hoc comparisons (for testing influence of aging and culturing on OX62+ DC cytokine mRNA expression), Mann-Whitney $U$ test (for testing the influence of aging on fresh OX62+ DC cytokine mRNA expression) and Student`s unpaired t-test (for testing influence of aging on fresh OX62+ DC subset distribution and cell surface antigen expression). All analyses were performed using SPSS version 18.0 software. Differences were considered to be significant when $\mathrm{p}<0.05$.

\section{RESULTS}

\section{Influence of aging on surface phenotype, cytokine mRNA expression and endocytic capacity of fiesh splenic OX62+DCs from DA rats}

\section{Aging does not influence the predominance of CD4- cells within splenic OX62+ DCs}

In splenic LDF from young rats, CD4- cells represented the predominant cell subset in OX62+ DC population, and their relative proportion did not change with aging (Fig. 1A). Consequently, CD4+:CD4- DC ratio was comparable in OX62+ DCs from young and aged rats. 

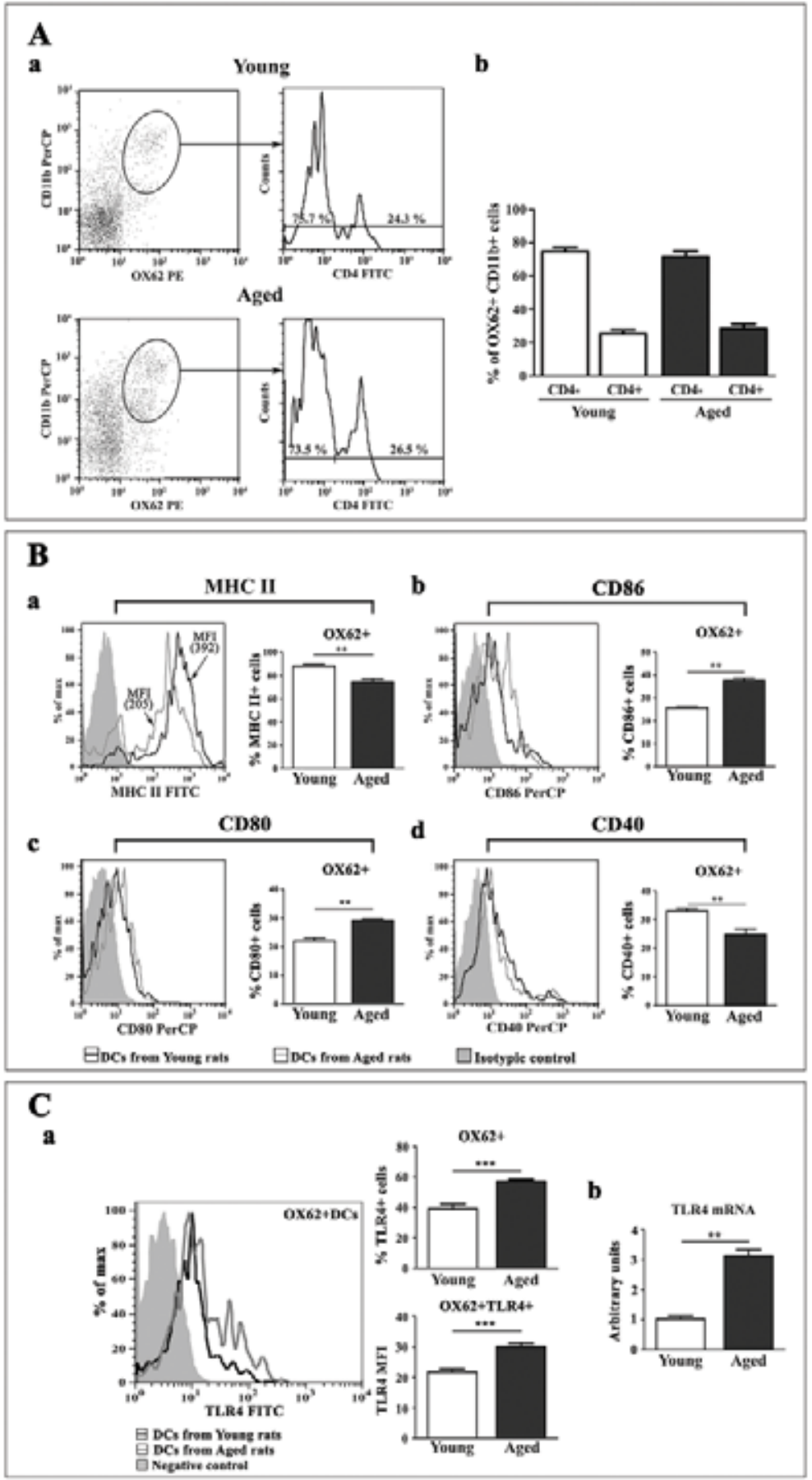

Figure 1. Influence of aging on surface phenotype of splenic OX62+ DCs from DA rats. 
Panel A. (a) The representative (right) flow cytometry histograms indicate the expression of CD4 on OX62+CD11b+ DCs gated on splenic low density fraction (LDF) cells isolated from young and aged rats as described in the section Material and Methods. Gating strategy for OX62+CD11b+ DCs is shown in (left) flow cytometry dot-plots indicating OX62 vs CD11b staining of splenic LDF isolated from (upper) young and (lower) aged rats. (b) The bar graph indicates the percentage of CD4+ and CD4- cells within splenic OX62+CD11b+ DC population. Results are expressed as mean \pm SEM $(n=6)$. The bar graphs indicate results from a single experiment. Similar data were obtained in three independent experiments

Panel B. The representative overlaid flow cytometry histograms show the expression of (a) MHC II, (b) CD86, (c) CD80 and (d) CD40 on gated splenic OX62+DCs. The bar graphs show the percentage of (a) MHC II+, (b) CD86+, (c) CD80+ and (d) CD40+ cells within splenic OX62+ DCs from young and aged rats. The data are expressed as mean \pm SEM $(\mathrm{n}=$ $12) ;{ }^{*} \mathrm{p}<0.01$. The figure indicates results from a single experiment. Similar data were obtained in three independent experiments.

Panel C. (a) The representative flow cytometry overlaid histograms indicate the expression of TLR4 on OX62+DCs isolated from young and aged rats as described in the section Material and Methods. The bar graphs show (upper) the percentage of TLR4+ cells within splenic OX62+ DC population and (lower) TLR4 mean fluorescence intensity (MFI) on TLR4+ splenic OX62+ DCs from young and aged rats. (b) The bar graph represents fold change in expression of mRNA for TLR4 in OX62+ DCs isolated from aged rats relative to the corresponding cells from young rats. HPRT was selected as the housekeeping gene to normalize for input cDNA variations as it displayed an optimal stability in our experimental system. The data are expressed as mean \pm SEM $(\mathrm{n}=12) ;{ }^{* *} \mathrm{p}<0.01,{ }^{* *} \mathrm{p}<0.001$. The figure indicates results from a single experiment. Similar data were obtained in three independent experiments

\section{Aging affects $0 \times 62+D C$ surface phenotype}

Flow cytometry analysis of the peptide-presenting MHC II and co-stimulatory (CD80, CD86 and CD40) molecules expression on OX62+ DCs from LDF revealed agerelated changes. The relative proportions of the cells expressing MHC II and CD40 within OX62+ DC diminished $(\mathrm{p}<0.01)$ with aging (Fig. 1Ba,d). Additionally, MHC II MFI was lower $(\mathrm{p}<0.01)$ on the MHC II+OX62+ DC from aged $(205.00 \pm 21.70)$ compared with the same cells from young rats $(392.00 \pm 25.52)$. This indicated a lower average surface density of MHC II on OX62+ DCs from aged animals [25]. To the contrary, the relative proportion of cells expressing CD80 and CD86 within OX62+ DC population increased $(\mathrm{p}<0.01)$ with aging $($ Fig. 1Bb,c).

\section{Aging augments TLR4 expression in OX62+DCs}

We also evaluated the expression of TLR4 in OX62+ DCs. This receptor recognizes LPS from Gram-negative bacteria, as well as endogenous ligands (e.g. heparansulfate and heat-shock proteins), which can be released as breakdown products after cell damage and tissue injury [26]. The relative proportion of the cells expressing TLR4 and TLR4 MFI on these cells was increased $(p<0.001)$ in OX62+ DC population from aged rats compared with young rats (Fig. 1Ca). In agreement with this finding, we found a greater $(\mathrm{p}<0.01)$ amount of TLR4 mRNA in the fresh splenic OX62+ DCs from aged relative to young rats (Fig. $1 \mathrm{Cb})$. 


\section{Aging affects expression of messengers for both inflammatory/ immunostimulatory and immunosuppressive cytokines in fresh 0X62+DCs}

In the next step, we examined the cytokine messenger profile in fresh OX62+ DCs. The amount of mRNA for TNF- $\alpha(p<0.05)$, IL-6 $(p<0.05)$ and IL-10 $(p<0.01)$ was greater in DCs from aged rats than in those from young ones (Fig. 2Aa,b,d). However, the amount of mRNA for TGF- $\beta$ did not significantly differ in suspensions of OX62+ DCs from aged and young rats, whereas that of IL-1 $\beta$ mRNA was diminished $(\mathrm{p}<0.05)$ in the OX62+ DC suspensions of aged rats than in those from young ones (Fig. 2Ac,e).
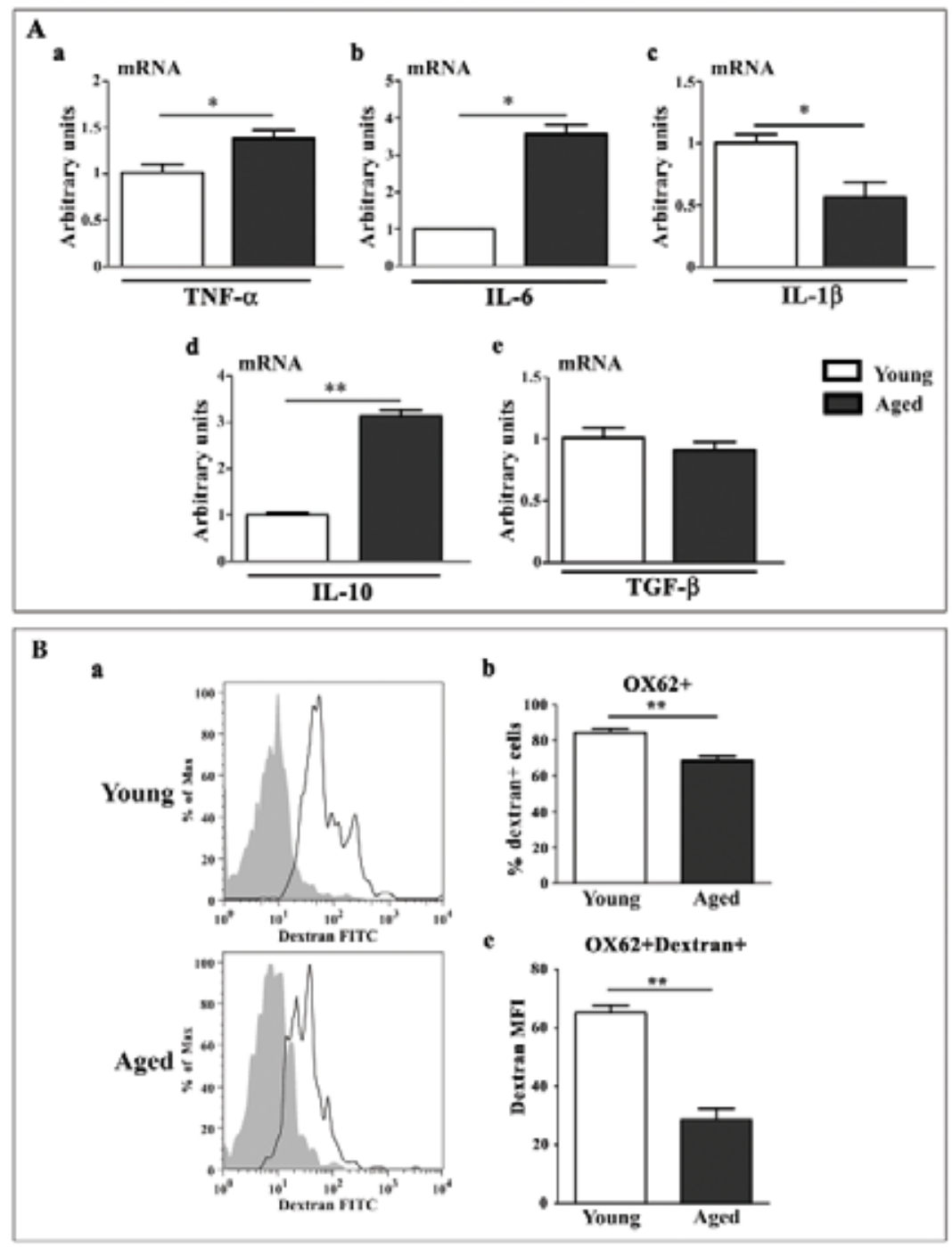

Figure 2. Aging affects cytokine mRNA expression profile and endocytic ability of splenic OX62+ DCs from DA rats. 
Panel A. The bar graphs represent fold change in expression of mRNA for (a) TNF- $\alpha$, (b) IL-6, (c) IL-1 $\beta$, (d) IL-10 and (e) TGF- $\beta$ cytokines in splenic OX62+ DCs freshly isolated from aged rats relative to the expression of corresponding cytokine mRNA in these cells from young rats. Splenic OX62+ DCs were isolated as described in the section Material and Methods. HPRT was selected as the housekeeping gene to normalize for input cDNA variations as it displayed an optimal stability in our experimental system. The data are expressed as mean \pm SEM (n $=12) ;{ }^{*}<0.05,{ }^{*} \mathrm{p}<0.01$. The figure indicates results from a single experiment. Similar data were obtained in three independent experiments.

Panel B. (a) The representative flow cytometry overlaid histograms show dextran-FITC endocytosis by OX62+ DCs gated on splenic low density fraction cells from (upper) young and (lower) aged rats at (grey histograms) $+4^{\circ} \mathrm{C}$ and (white histograms) $37^{\circ} \mathrm{C}$. The bar graphs show (b) the percentage of dextran + cells within OX62+ DC population and (c) dextran mean fluorescence intensity (MFI) of OX62+ dextran+ DCs from young and aged rats. The data are expressed as mean $\pm \operatorname{SEM}(\mathrm{n}=12) ;{ }^{* *} \mathrm{p}<0.01$. The figure indicates results from a single experiment. Similar data were obtained in three independent experiments.

\section{Aging diminishes endocytic capacity of fresh OX62+DCs}

Furthermore, the functional capacity of OX62+ DCs was assessed through flow cytometry analysis of their ability to uptake FITC-labeled dextran by endocytosis. The analysis showed that aging reduced both the percentage of dextran+ cells in OX62+ DC suspensions and the amount of endocytosed dextran (judging by dextran MFI in dextran+ cells) (Fig. 2B).

\section{Influence of aging on the surface phenotype of in vitro LPS-stimulated splenic 0X62+DCs and their cytokine expression}

\section{Aging affects LPS-elic ited changes in 0X62+ DC surface phenotype}

Next, we analyzed the putative effects of aging on invitromaturation of splenic OX62+ DCs in the presence of LPS (LPS+ cultures) and in the absence of LPS (control LPScultures). As previously shown [17,27], OX62+ DCs from rats of both ages when put in culture medium alone underwent "spontaneous" activation/maturation as shown by the up-regulation of MHC II and co-stimulatory molecules. Namely, we found a substantial increase $(\mathrm{p}<0.001)$ in the percentage of positive cells and MFI for both MHC II and CD80 molecules following overnight OX62+ DC incubation in medium (Fig. 3Aa,c). In addition, the percentage of CD86+ cells was increased $(\mathrm{p}<0.001)$ in the LPS- cultures from young rats, whereas that of CD40+ cells was greater in the LPScultures from aged rats comparing with the starting (sorted by magnetic separation) OX62+ DCs from age-matched rats (Fig. 3Ab,d). It is noteworthy that magnetic separation did not significantly affect OX62+ DC surface phenotype (Fig. 1B and Fig. 3). LPS did not significantly influence the cell survival in OX62+ DC cultures from either young $(32.55 \% \pm 1.95 \%$ in LPS- vs. $29.85 \pm 1.65 \%$ in LPS + cultures) or aged $(30.60 \% \pm 1.70 \%$ in aged LPS- vs. $32.85 \pm 2.15 \%$ in aged LPS + cultures) rats.

Following LPS stimulation, CD4+:CD4- subset ratio in DC cultures from young and aged rats remained comparable to that in fresh DC suspensions $(0.34 \pm 0.09$ in aged vs. $0.52 \pm 0.13$ in young rats). However, LPS exhibited a differential influence on the expression of MHC II and co-stimulatory molecules on DCs from young and 
aged rats. Comparing with age-matched control cultures, the average MHC II surface density (judging by MHC II MFI) increased $(\mathrm{p}<0.05)$ only on DCs in LPS cultures from young rats $($ Fig. 3Ba). In addition, LPS increased $(\mathrm{p}<0.001)$ the percentage of cells expressing CD80 in DC cultures from young rats compared with the age-matched control cultures (Fig. 3Bc). On the other hand, in the presence of LPS, in OX62+ DC cultures from rats of both ages the percentage of CD86+ cells $(p<0.01$ and $p<0.05$ in young and aged rats, respectively) and CD86 surface density $(\mathrm{p}<0.001)$ increased relative to age-matched control cultures (Fig. 3Bb).

Comparing phenotypic characteristics of LPS-stimulated DCs from young and aged rats, in respect to the expression of MHC II and co-stimulatory molecules, we found that the proportion of $\mathrm{CD} 86+$ cells was diminished $(\mathrm{p}<0.05)$ in the cultures from aged rats (Fig. 3Bb). In addition, the average surface density of MHC II and CD40 was lower $(\mathrm{p}<0.001)$ on cells from LPS-stimulated DC cultures of aged compared with young rats (Fig. 3Ba,d).

\section{A "Spontaneous" activation/maturation}$$
\text { a }
$$

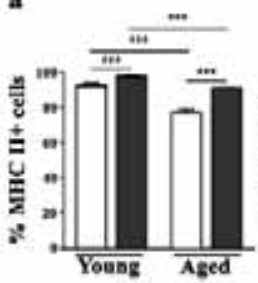

b

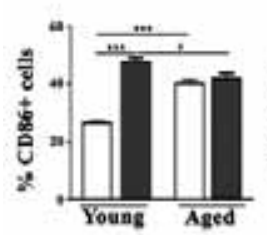

c

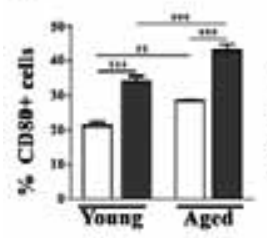

d

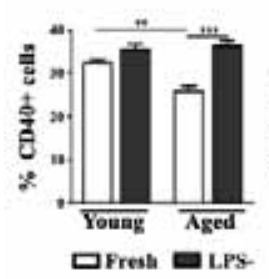

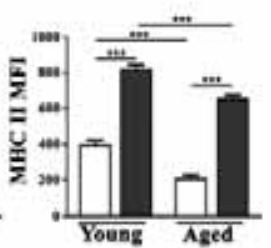
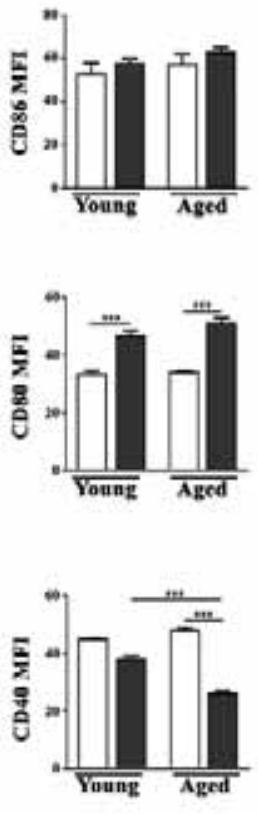

\section{B LPS-induced activation/maturation}
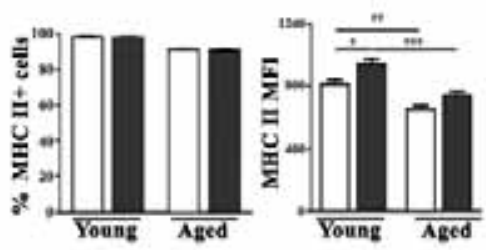

b
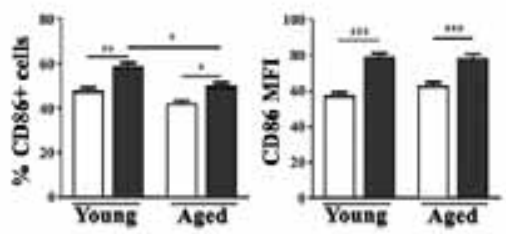

e
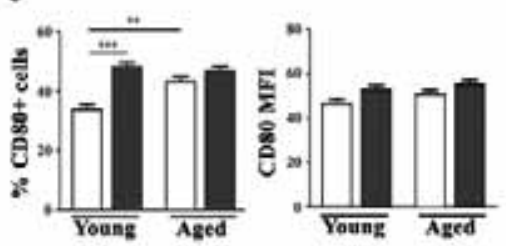

d
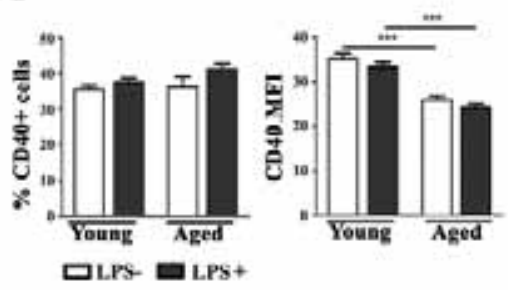
Figure 3. Influence of aging on the "spontaneous" and LPS-induced activation/maturation of splenic OX62+ DCs from DA rats in culture.

The bar graphs represent the surface phenotype of splenic OX62+ DCs from young and aged DA rats cultured (Panel A) in the absence ("spontaneous" activation/maturation) and (Panel B) the presence of LPS (LPS-induced activation/maturation).

Panel A. The bar graphs show (left) the percentage of (a) MHC II+, (b) CD86+, (c) CD80+ and (d) CD40+ cells within splenic OX62+ DCs from young and aged rats freshly isolated (Fresh) and cultured without LPS (LPS- cultures) and (right) the mean fluorescence intensity (MFI) of (a) MHC II, (b) CD86, (c) CD80 and (d) CD40 on the corresponding positive cells. The OX62+ DCs were isolated and cultured as described in the section Material and Methods. The data are expressed as mean $\pm \operatorname{SEM}(\mathrm{n}=12) ;{ }^{*} \mathrm{p}<0.05 ;{ }^{* *} \mathrm{p}<0.01 ;{ }^{* * *} \mathrm{p}<0.001$. The figure indicates results from a single experiment. Similar data were obtained in three independent experiments. Two-way ANOVA showed a significant difference in the percentage of MHC II $+(p<0.01)$, CD86+ $(p<0.001)$ and CD40+ cells $(p<0.01)$ and MFI for CD40 $(p<0.001)$ on splenic OX62+ DCs from young and aged rats following overnight culturing with significant interactions between the effects of aging and culturing.

Panel B. The bar graphs show (left) the percentage of (a) MHC II+, (b) CD86+, (c) CD80+ and (d) CD40+ cells within splenic OX62+ DCs from young and aged rats cultured in the absence (LPS- cultures) and in the presence of LPS (LPS+ cultures) and (right) the MFI of (a) MHC II, (b) CD86, (c) CD80 and (d) CD40 on the corresponding positive cells.. The data are expressed as mean $\pm \operatorname{SEM}(\mathrm{n}=12) ;{ }^{*} \mathrm{p}<0.05 ;{ }^{* *} \mathrm{p}<0.01 ;{ }^{* * *} \mathrm{p}<0.001$. The figure indicates results from a single experiment. Similar data were obtained in three independent experiments. Two-way ANOVA showed a significant difference in the percentage of CD80+ cells $(p<0.01)$ within splenic OX62+ DCs following LPS stimulation with significant interactions between the effects of aging and LPS.

\section{Aging affects expression of inflammatory/immunostimulatory and immunosuppressive cytokines by OX62+ DC upon LPS stimulation}

Considering that in response to LPS stimulation DCs along with the changes in the cell surface molecule expression, begin to produce cytokines that impact T-cell differentiation/polarization, we analyzed the expression of various polarizing cytokines at both protein and mRNA levels in LPS+ and LPS- (control) OX62+ DC cultures.

\section{Cytokine protein expression}

The levels of inflammatory/immunostimulatory (IL-12, IL-6, TNF- $\alpha$ ) cytokines and immunosuppressive (IL-10) cytokine were comparable in control DC cultures from aged and young rats (Fig. 4Aa,b,c,e). However, the level of IL-23 was higher $(p<0.01)$ in control DC cultures from aged rats than in the corresponding cultures from young ones (Fig. 4Ad). We failed to detect measurable levels of TGF- $\beta$ in the supernatants of either LPS-stimulated or control OX62+ DCs cultures (data not shown).

After LPS stimulation, the levels of IL-6 and IL-10 increased $(\mathrm{p}<0.001)$ in DC cultures from aged rats (Fig. 4a,e), whereas those of IL-12, IL-23 and TNF- $\alpha$ were unaffected (Fig. 4Ab,c,d). On the other hand, in LPS + DC cultures from young rats only the level of TNF- $\alpha$ increased $(p<0.001)$ when compared with the corresponding control cultures (Fig. 4Ab).

In addition, the levels of all tested cytokines, except for TNF- $\alpha$ and IL-12, were greater $(p<0.001)$ in LPS + cultures from aged rats than in LPS + cultures from young ones 
(Fig. 4Aa,d,e). The level of TNF- $\alpha$ was lower $(\mathrm{p}<0.05)$ in LPS $+\mathrm{DC}$ cultures from aged compared with LPS + cultures from young rats, whereas that of IL-12 did not significantly differ (Fig. 4Ab,c).

\section{A}

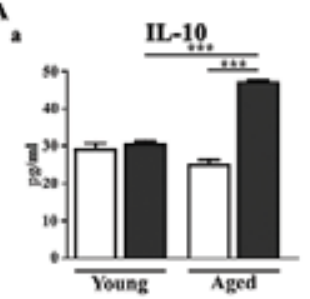

b

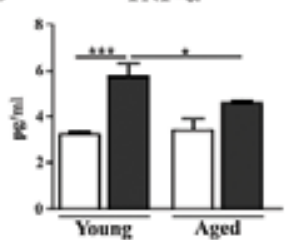

c

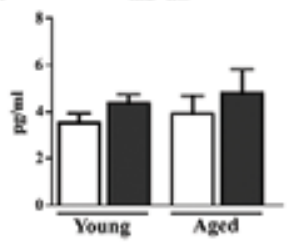

d

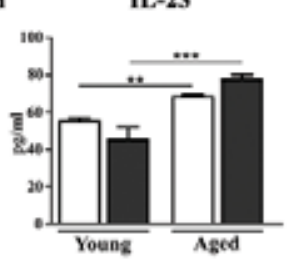

e
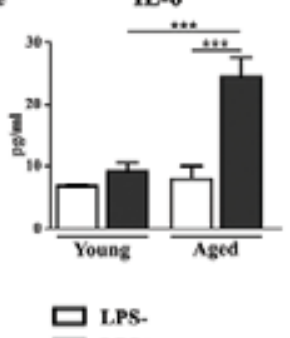

B

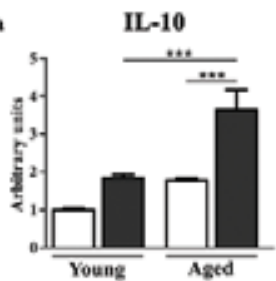

b

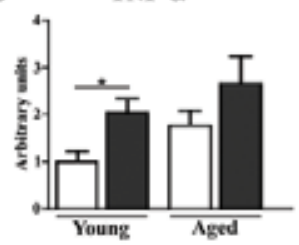

$c$

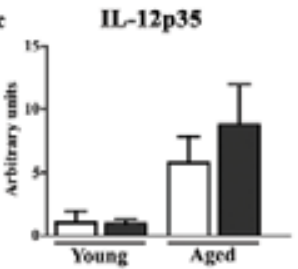

d

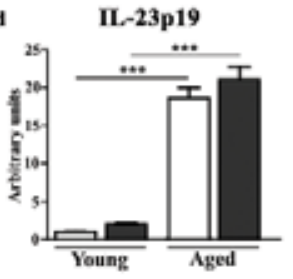

e IL-6
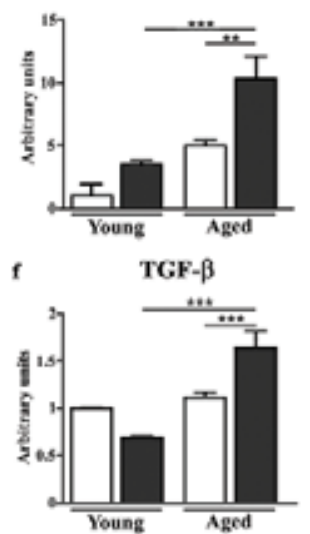
Figure 4. Influence of aging on the expression of cytokines in LPS-activated/matured OX62+ DCs from DA rats.

The bar graphs represent cytokine expression at (Panel A) protein and (Panel B) mRNA levels in splenic OX62+ DCs from young and aged rats cultured in the absence (LPS- cultures) and in the presence of LPS (LPS+ cultures). The OX62+ DCs were isolated and cultured as described in Material and Methods section.

Panel A. Concentrations of (a) IL-10, (b) TNF- $\alpha$, (c) IL-12, (d) IL-23 and (e) IL-6 in supernatants from splenic OX62+ DCs of young and aged rats cultured in the absence (LPScultures) and in the presence of LPS (LPS+ cultures). The data are expressed as mean \pm SEM ( $\mathrm{n}=12$ ); ${ }^{*} \mathrm{p}<0.05 ;{ }^{*} \mathrm{p}<0.01,{ }^{* *} \mathrm{p}<0.001$. The figure indicates results from a single experiment. Similar data were obtained in three independent experiments. Two-way ANOVA showed significant differences in the concentration of IL-10 ( $p<0.001)$, TNF- $\alpha(p<0.05)$, IL-23 $(p<0.001)$ and IL-6 $(p<0.01)$ in OX62+ DC cultures following LPS-stimulation with significant interactions between the effect of aging and LPS.

Panel B. The bar graphs represent the fold change in the expression of mRNA for (a) IL-10, (b) TNF- $\alpha$, (c) IL-12p35, (d) IL-23p19, (e) IL-6 and (f) TGF- $\beta$ in OX62+ DCs from aged rats cultured in the absence of LPS (LPS- cultures) and in OX62+ DCs from young and aged rats cultured in the presence of LPS (LPS+ cultures) relative to the expression of corresponding cytokine mRNA in OX62+ DCs from young rats cultured in the absence of LPS. HPRT was selected as the housekeeping gene to normalize for input cDNA variations as it displayed optimal stability in our experimental system. The data are expressed as mean \pm SEM $(n=12)$; ${ }^{*} \mathrm{p}<0.05 ;{ }^{* *} \mathrm{p}<0.01,{ }^{* * *} \mathrm{p}<0.001$. The figure indicates results from a single experiment. Similar data were obtained in three independent experiments. Two-way Kruskal-Wallis test showed a significant difference for the expression of mRNA for TGF- $\beta(p<0.001)$, IL- $6(p<0.01)$ and IL-10 ( $\mathrm{p}<0.001)$ in OX62+ DC cultures following LPS-stimulation with significant interactions between the effect of aging and LPS.

\section{Cytokine mRNA expression}

In agreement with the data obtained by quantifying cytokine protein levels, we failed to detect any significant difference in the expression of mRNAs for IL-12p35, IL-6, TNF- $\alpha$ and IL-10 in DC from control cultures of young and aged rats (Fig. 4Ba,b,c,e). In addition, the expression of TGF- $\beta$ mRNA was comparable in DCs from control cultures of young and adult rats (Fig. 4Bf). However, the expression of mRNA for IL-23p19 was greater $(\mathrm{p}<0.001)$ in DCs from control cultures of aged rats than in corresponding cultures of young animals (Fig. 4Bd).

The analyses of the influence of LPS on the expression of cytokine messengers showed a similar pattern of age-related changes to that observed in the expression of the corresponding cytokine proteins. Namely, LPS augmented the expression of mRNAs for IL-6 $(\mathrm{p}<0.01)$ and IL-10 $(\mathrm{p}<0.001)$ in DCs from aged rats (Fig. 4Ba,e). In addition, in these cells LPS increased $(p<0.001)$ TGF- $\beta$ mRNA expression (Fig. $4 \mathrm{Bf})$. On the other hand, in DCs from young rats LPS increased $(\mathrm{p}<0.05)$ only the expression of TNF- $\alpha$ mRNA (Fig.4Bb).

Comparing the expression of mRNAs for various cytokines in LPS-stimulated DCs from aged and young rats, we found that the expression of mRNA for all the tested cytokines, except for IL-12p35 and TNF- $\alpha$, was greater $(\mathrm{p}<0.001)$ in DCs from aged rats (Fig. 4Ba,d,e,f). Expression of IL-12p35 and TNF- $\alpha$ mRNAs did not significantly differ between LPS-matured DCs from young and aged rats (Fig. 4Bb,c). 


\section{Aging alters OX62+ DC stimulatory and polarizing capacity of LPS-matured OX62+DC in allogeneic MLR}

\section{Aging diminishes allostimulatory capac ity of LPS-matured DCs}

Next, we investigated the capacity of OX62+ DCs to promote proliferation of CFSElabeled allogeneic CD4+ T cells. We measured the division index and the percentage of TCR $\alpha \beta+\mathrm{CD} 4+$ cells with a diminished amount of CFSE in CD4+ T-cell cocultures with control and LPS-stimulated OX62+ DCs. Although allogeneic CD4+ $\mathrm{T}$ cells proliferated in the presence of control DCs from rats of both ages, both the examined parameters of CD4+ T cell proliferation had greater values when LPS-stimulated OX62+ DCs were used as stimulators. Additionally, LPS-stimulated DCs from aged rats, irrespective of OX62+ DC:CD4+ T-cell ratio, were less potent as CD4+ T-cell proliferation stimulators (judging by both the division index and percentage of CD4+TCR $\alpha \beta+$ cells with diminished amount of CFSE) than LPS-stimulated DCs from young rats (Fig. 5A). Also, irrespective of age of OX62+ DC donor, the values of both the parameters of CD4+ T cell proliferation exhibited cell ratio dependent alterations, showing the maximum value at the highest (1:5) OX62+ DC:CD4+ Tcell ratio (Fig. 5A).Moreover,analysis of the relative number of cells with diminished CFSE, which could be a reliable parameter for analyzing the magnitude of T-cell proliferative response in MLR [28] indicated that the proliferative response of CD4+T cells at the highest ratio in cultures with LPS-stimulated DCs from aged rats corresponded to that at about 1:20 ratio in cultures with LPS-stimulated DCs from young rats.

\section{Aging diminishes polarizing capacity of LPS-stimulated DCs}

Finally,we examined supernatants from co-cultures of allogeneic CD4+ T-cells with both control (cultivated in the absence of LPS) and LPS-matured OX62+ DCs for the presence of IL-10, IL-4, IFN- $\gamma$ and IL-17.The levels of IL-10 and IL-4 levels in the supernatants of CD4+T-cell co-cultures with control DCs from young rats did not differ from those in the supernatants of CD4+ T-cell co-cultures with control DCs from aged rats (Fig. 5Ba,b).In addition,LPS stimulation did not significantly influence the capacity of DCs to stimulate the production of these cytokines in MLR (Fig. $5 \mathrm{Ba}, \mathrm{b})$.

On the other hand, we measured greater levels $(\mathrm{p}<0.05)$ of IL-17, Th17 signature cytokine, in the supernatants of CD4+ T-cell co-cultures with control DCs from aged rats compared with the corresponding co-cultures with control DCs from young rats (Fig. 5Bc). LPS did not influence the capacity of DCs from either young or aged rats to induce secretion of IL-17 by CD4+ T cells in MLR, so IL-17 levels remained higher $(\mathrm{p}<0.05)$ in CD4+ T-cell co-cultures with LPS-stimulated DCs from aged compared with those with the corresponding cells from young rats (Fig. 5Bc). Considering that despite of an increased production of IL- 6 and TGF- $\beta$, i.e. Th17 polarizing cytokines, by LPS-stimulated DCs from aged rats, the levels of IL-17 were comparable in CD4+ 
T-cell co-cultures with LPS-stimulated and control DCs from aged rats, we looked for the mechanism/s underlying this phenomenon. Given that: (i) LPS increased the expression of IL-10, which constrains Th17 cell development in DCs from aged rats and (ii) IL-10 could constrain Th17 cell development through limiting IL-1 $\beta$ production by DCs $[29,30]$, we additionally quantified IL-1 $\beta$ levels in DC cultures. As expected from previous studies $[29,30]$, the levels of IL-1 $\beta$ were diminished $(\mathrm{p}<0.05)$ in LPS-stimulated cultures from aged rats $(28.17 \pm 0.48 \mathrm{pg} / \mathrm{ml})$ compared with control cultures $(42.33 \pm 5.77 \mathrm{pg} / \mathrm{ml})$ from aged-matched animals. Thus, it seems likely that the increased levels of IL-10 in CD4+ T-cell co-cultures with LPS-stimulated DCs from aged rats restricted CD4+ T-cell production of IL-17.
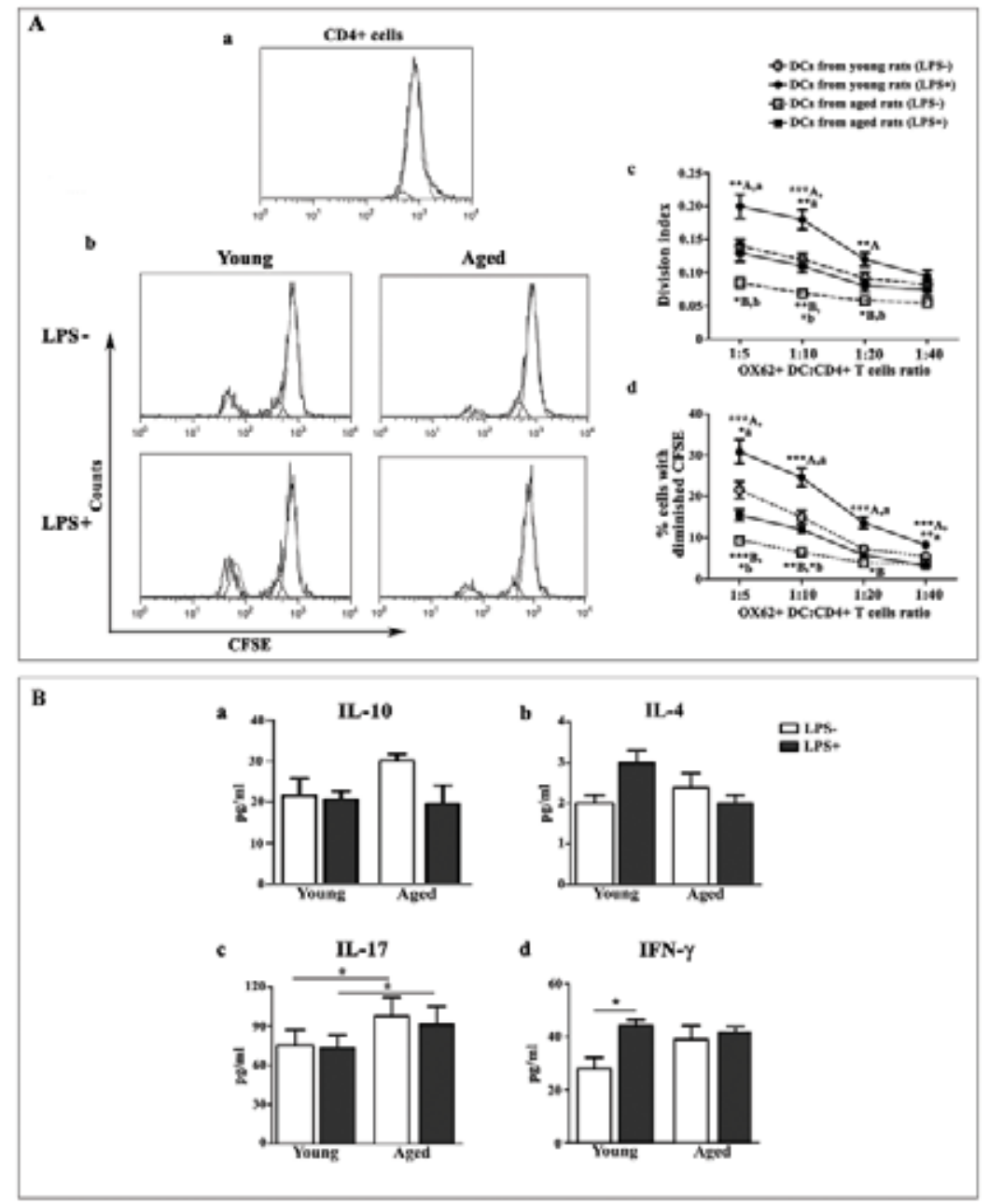

Figure 5. Aging diminishes allostimulatory capacity and Th1 polarizing capacity of LPSactivated/matured splenic OX62+ DCs from DA rats. 
Panel A. Representative flow cytometry profiles generated by the proliferation platform of the FlowJo software indicate CFSE labeling of (a) unstimulated allogeneic TCR $\alpha \beta+C D 4+$ cells and (b) allogeneic TCR $\alpha \beta+\mathrm{CD} 4+$ cells stimulated in mixed lymphocyte reaction (MLR) with splenic OX62+ DCs cultured in (upper) the absence of LPS (LPS- cultures) and (lower) in the presence of LPS (LPS+ cultures) at 1:5 ratio, from (left) young and (right) aged rats. The OX62+ DCs were isolated and cultured as described in the section Material and Methods. The line graphs indicate (c) division index and (d) percentage of TCR $\alpha \beta+C D 4+$ lymphocytes with diminished intensity of CFSE fluorescence in allogeneic TCR $\alpha \beta+\mathrm{CD} 4+$ cell co-cultures with splenic OX62+ DCs from young and aged rats cultured in the absence (LPS- cultures) or presence of LPS (LPS + cultures) at various ratios. Division index was calculated using the proliferation platform of the FlowJo software. The data are expressed as mean \pm SEM ( $\mathrm{n}=$ 12); ${ }^{\mathrm{A}} \mathrm{OX} 62+\mathrm{DCs}$ from young rats (LPS + ) vs OX62+ DCs from aged rats (LPS+); ${ }^{\mathrm{a} O X 62+}$ DCs from young rats (LPS+) vs OX62+ DCs from young rats (LPS-); ${ }^{\mathrm{B}} \mathrm{OX} 62+$ DCs from aged rats (LPS-) vs OX62+ DCs from young rats (LPS-); ${ }^{\text {OOX } 62+~ D C s ~ f r o m ~ a g e d ~ r a t s ~(L P S+) ~}$ vs OX62+ DCs from aged rats (LPS-); ${ }^{*}<<0.05$; **p $<0.01,{ }^{* * *} \mathrm{p}<0.001$.

Panel B. The bar graphs represent changes in (a) IL-10, (b) IL-4, (c) IL-17 and (d) IFN- $\gamma$ concentrations in the co-cultures of allogeneic CD4+ T cells and splenic OX62+ DCs from young and aged rats cultured in the presence of LPS (LPS + cultures) and in the absence of LPS (LPS- cultures). The OX62+ DCs were isolated and cultured as described in the section Material and Methods. The data are expressed as mean \pm SEM $(n \geq 6) ;{ }^{*} p<0.05$. The figure indicates results from a single experiment. Similar data were obtained in three independent experiments

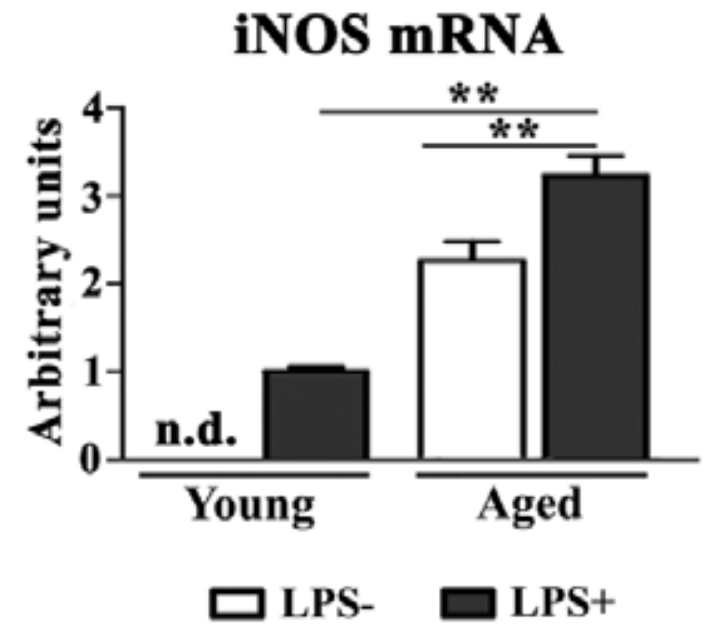

Figure 6. Aging increases iNOS expression in LPS-activated/matured OX62+ DCs from DA rats.

The bar graph represents the fold change in the expression of iNOS mRNA in OX62+ DCs from aged rats cultured in the presence (LPS+ cultures) and in the absence of LPS (LPScultures) relative to its expression in OX62+ DCs from young rats cultured in the presence of LPS. Note that the expression of iNOS mRNA in DCs from young rats cultured in the absence of LPS was not detectable (n.d.).The OX62+ DCs were isolated and cultured as described in Material and Methods section. HPRT was selected as the housekeeping gene to normalize for input cDNA variations as it displayed optimal stability in our experimental system. The data are expressed as mean $\pm \operatorname{SEM}(\mathrm{n}=12) ;{ }^{*} \mathrm{p}<0.01$. The figure indicates results from a single experiment. Similar data were obtained in three independent experiments. 
Furthermore, we found that levels of IFN- $\gamma$, a Th1 signature cytokine, were comparable in the supernatants of CD4+ T-cell co-cultures with control DCs from young and aged rats (Fig. 5Bd). However, differently from LPS-stimulated DCs from aged rats, which did not significantly influence IFN- $\gamma$ production by $\mathrm{CD} 4+\mathrm{T}$ cells, the corresponding cells from young rats increased $(p<0.05)$ the production of this cytokine by $\mathrm{CD} 4+$ T cells in MLR (Fig. 5Bd). Since LPS did not influence the expression of IL-12, a major cytokine driving Th1 polarization, in DCs from young rats, we examined the capacity of LPS-stimulated DCs from these animals to affect CD4+ cell sensitivity to this cytokine action. Given that NO increases sensitivity to IL-12 action, through up-regulation of IL-12 receptor expression [31], the expression of iNOS, the major $\mathrm{NO}$-generating enzyme was additionally examined. We found measurable levels of mRNA for iNOS only in control (LPS-) DC cultures from aged rats (Fig. 6). Upon LPS stimulation the amount of iNOS achieved measurable level in DCs from young rats, but the amount of this enzyme remained less $(p<0.01)$ than in LPS-stimulated DCs from aged rats (Fig. 6).

\section{DISCUSSION}

This study confirmed that in the rat cell subset composition of splenic DCs correlates with strain-specific sensitivity to induction of autoimmune diseases [18,20]. Namely, differently from splenic OX62+ DCs of young AO rats (relatively resistant to induction of several Th1/Th17-mediated autoimmune diseases), which displays CD4+ cell predominance [17], this cell population from age-matched DA rats (highly susceptible to induction of Th1/Th17-mediated autoimmune diseases) was characterized by a greater proportion of CD4- cells. Comparing with the corresponding control cells, LPS-stimulated splenic OX62+ DCs from young DA rats in allogeneic MLR exhibited a greater capacity to increase production of IFN $-\gamma$, a signature Th1 cytokine, by CD4+ $\mathrm{T}$ cells. In agreement with this finding, LPS-stimulated OX62+ DCs from young rats, expressed more TNF- $\alpha$ and iNOS than the corresponding cells cultivated in the absence of LPS. However, contrary to our expectations, LPS did not significantly influence the production of IL-12 by OX62+ DCs s from young rats. Given that NO selectively up-regulates the expression of IL-12 receptor [31], the obvious discrepancy between IL-12 production capacity of LPS-stimulated OX62+ DCs and their performance in MLR could be reconciled by the greater amount of iNOS in LPS-stimulated OX62+ DCs from young compared with that in the cells unstimulated by LPS. In other words, it may be assumed that the greater sensitivity of the responding CD4+ cells to IL-12 signaling contributed to the greater IFN- $\gamma$ production in $\mathrm{CD} 4+\mathrm{T}$-cell co-cultures with LPS-stimulated OX62+ DCs from young rats compared with their co-cultures with control (LPS-) DCs from age-matched rats.

Furthermore, aging affected not only the surface phenotype of OX62+ DCs from aged DA rats by increasing the surface expression of co-stimulatory CD80 and CD86 molecules, but it reduced their capacity to uptake dextran compared with the 
corresponding cells from young rats. The age-related decrease in endocytic capacity is also registered in human DCs [32]. Although factors/mechanisms underlying agerelated changes in endocytic capacity of aged human DCs have not been fully elucidated, there are findings indicating that the age-related impairment of DC phosphoinositide 3-kinase (PI3K)/AKT signaling pathway [11], could contribute to this phenomenon. The defective functioning of this signaling pathway in DCs of elderly is associated with the up-regulation of proinflammatory cytokine expression in these cells, which is registered in both old mice and humans [11,32,33]. Namely, it has been shown that the PI3K/AKT-signaling pathway may function as an endogenous negative feedback, or compensatory mechanism, that serves to limit proinflammatory cytokines expression in response to injurious stimuli. Furthermore, Guha and Mackman [34] have reported that the PI3K-AKT pathway imposes a braking mechanism to limit the expression of proinflammatory mediators in LPS-treated monocytes. Therefore, the augmented expression of mRNAs for TNF- $\alpha$ and IL-6 in OX62+ DCs from aged rats is consistent with the impaired endocytic capacity of these cells. Furthermore, if one accepts the previous assumption, the opposing effect of aging on endocytic capacity of OX62+ DCs from AO rats [17], which exhibit the age-related decrease in the expression of IL-6, does not come as a surprise.

Upon LPS stimulation, despite of the age-related increase in surface density of TLR4, the examined DCs from aged DA rats displayed a less mature phenotype (mirrored in the diminished MHC II and CD86, CD40 molecule expression) than the corresponding cells from young rats. There are several plausible explanations for these findings. Firstly, it should be pointed that studies in humans indicated age-associated deregulation of TLR function (due to changes in both TLR surface expression and the specific pathways regulating TLR4 signal transduction) resulting in the impairment in TLR signaling [35]. Therefore, despite the increase in the surface TLR4 expression on OX62+ DCs from aged rats, an impaired TLR4 function [35], and consequently a weakened activation of these cells upon stimulation, may be assumed. Secondly, given that IL-10 is shown to limit LPS-mediated DC maturation, acting in an autocrine manner [36], it may be assumed that the age-related increase in OX62+ DC expression of IL-10 also contributed to the incomplete maturation of these cells from aged rats. Thirdly, the level of TNF- $\alpha$, which up-regulates co-stimulatory molecule expression on DCs [37,38], was lower in LPS-stimulated OX62+ DC cultures from aged rats than those from young ones. Given that IL-10 negatively regulates TNF- $\alpha$ synthesis, acting in an autocrine manner [36], the latter finding is consistent with up-regulation of IL10 expression in LPS-stimulated OX62+ DCs from aged rats.

Furthermore, LPS-stimulated OX62+ DCs from aged DA rats, as those from AO rats of the chronobiologically same age [17], exhibited the diminished allostimulatory capacity when compared with the corresponding cells from young rats of the same strain. Similar findings were obtained in studies which examined the influence of aging on human and murine DCs allostimulatory capacity [11,13,32,39]. Given that stimulatory capacity of DCs in MLR mainly depends on their MHC II surface 
expression [40], the diminished allostimulatory capacity of LPS-stimulated OX62+ DCs from aged rats could be related to the age-related decrease in MHC II surface density on these cells. In addition, the age-related decrease in allostimulatory capacity of rat DCs could reflect augmented iNOS expression in LPS-matured DCs from aged DA rats relative to that in the corresponding cells from young rats. Namely, there are data indicating that age-related increase in oxidative stress interferes with the ability of DCs from aged mice to mount an efficient MHC II-restricted immune response [41].

Finally, differently from LPS-stimulated OX62+ DCs from aged AO rats, which exhibit a striking age-related increase in capacity to stimulate IFN- $\gamma$ and IL-17 production in allogeneic CD4+ T cells [17], LPS-stimulated OX62+ DCs from aged DA rats did not significantly influence the production of these cytokines in allogeneic CD4+ T cells when compared with age-matched DCs that were not stimulated by LPS. Namely, although compared with young LPS-stimulated OX62+ DCs the corresponding cells from aged rats produced comparable IL-12 levels and contained a larger amount of iNOS mRNA, these cells were inefficient in stimulating IFN- $\gamma$ production by allogeneic CD4+ T cells in MLR. There are several plausible explanations for these findings. Firstly, since the direct TLR-dependent IL-12 production in DCs does not necessarily correlate with the CD40-dependent IL-12 production [42], the lack of measurable response in IFN- $\gamma$ production could be linked with markedly lower CD40 surface density on LPS-stimulated OX62+ DCs from aged DA rats compared with the corresponding cells from young rats. Secondly, the lack of IFN- $\gamma$ stimulatory capacity of LPS-matured DCs from aged rats may reflect a prominent increase in their expression of IL-10 and IL-6 compared with age-matched unstimulated OX62+ DCs and LPS-stimulated DCs from young rats. These cytokines negatively influence IFN- $\gamma$ synthesis and Th1 polarization [43-46]. Furthermore, differential influence of aging on the capacity of OX62+ DCs from DA and AO rats to induce Th1 response may be associated with findings indicating that these cells from aged $\mathrm{AO}$ rats do not up-regulate IL-10 synthesis in response to LPS [17]. Moreover, the up-regulation of IL-10 expression after LPS stimulation was detected only in OX62+ DCs from young AO rats, which were inefficient in inducing Th1 response [17].

It should also be pointed that although LPS-stimulated OX62+ DCs from aged DA rats failed to increase IL-17 levels in MLR compared with control unstimulated OX62+ DCs from aged, the levels of these cytokines were higher in CD4+ T-cell co-cultures with LPS-stimulated OX62+ DCs from aged rats than in CD4+ T-cell co-cultures with corresponding cells from young rats. This reflected the increase in IL-17 levels in CD4+T-cell co-cultures with unstimulated OX62+DCs from aged rats. Given that sustained production of IL-17 in CD4+ T cells requires IL-23 [47-49] the previous finding could be linked with the age-related rise in the expression of IL-23 in DCs cultivated in the absence of LPS. Additionally, the lack of increase in IL-17 level in CD4+ T-cell co-cultures with LPS-stimulated DCs from aged rats compared with co-cultures with age-matched unstimulated DCs, could reflected the diminished expression of IL-1 $\beta$ due to the enhanced production of IL-10 in these cells [29,30,50]. 
The differences in IL-17 driving capacity of LPS-stimulated OX62+ DCs from aged DA and AO rats in MLR [17] could also reflect the differential influence of aging on IL-10 production in DCs from these two genetically distinct strains.

Overall, the hereby presented findings suggest that aging might affect the ability of DA rats to mount an efficient Th1 immune response, and consequently their susceptibility to induction of Th1/Th17-mediated diseases. This assumption is corroborated by our data indicating that the age-related increase in OX62+ DC Th1/ Th17 polarizing capacity augments susceptibility of aged AO rats to experimental autoimmune encephalomyelitis, broadly used experimental model of multiple sclerosis [17]. To further support this option are data indicating strain specificities in age-related changes in the rat susceptibility to experimental autoimmune encephalomyelitis [5153]. Furthermore, the study indicates that it is necessary to consider the genetic background in designing new strategies to improve the immune system function at different ages.

\section{Acknowledgment}

This work was supported by the grant $\mathrm{N}^{\circ} 175050$ from the Ministry of Education, Science and Technological Development of the Republic of Serbia.

\section{REFERENCES}

1. Banchereau J, Steinman RM: Dendritic cells and the control of immunity. Nature 1998,392: 245-252.

2. Munz C, Steinman RM, Fujii S: Dendritic cell maturation by innate lymphocytes: coordinated stimulation of innate and adaptive immunity. J Exp Med 2005, 202:203-207.

3. Voisine C, Hubert FX, Trinite B, Heslan M, Josien R: Two phenotypically distinct subsets of spleen dendritic cells in rats exhibit different cytokine production and $\mathrm{T}$ cell stimulatory activity. J Immunol 2002, 169:2284-2291.

4. Hubert FX, Voisine C, Louvet C, Heslan M, Josien R: Rat plasmacytoid dendritic cells are an abundant subset of MHC class II+ CD4+CD11b-OX62- and type I IFN-producing cells that exhibit selective expression of Toll-like receptors 7 and 9 and strong responsiveness to CpG. J Immunol 2004, 172:7485-7494.

5. Burkle A, Caselli G, Franceschi C, Mariani E, Sansoni P, Santoni A, Vecchio G, Witkowski JM, Caruso C: Pathophysiology of ageing, longevity and age related diseases. Immun Ageing 2007, 4:4.

6. Gruver AL, Hudson LL, Sempowski GD: Immunosenescence of ageing. J Pathol 2007 211:144-156.

7. Aspinall R, Goronzy JJ: Immune senescence. Curr Opin Immunol 2010, 22:497-499.

8. Nikolich-Zugich J: T cell aging: naive but not young. J Exp Med 2005, 201:837-840.

9. Salam N, Rane S, Das R, Faulkner M, Gund R, Kandpal U, Lewis V, Mattoo H, Prabhu S, Ranganathan V, Durdik J, George A, Rath S, Bal V: T cell ageing: effects of age on development, survival \& function. Indian J Med Res 2013, 138:595-608. 
10. Grolleau-Julius A, Garg MR, Mo R, Stoolman LL, Yung RL: Effect of aging on bone marrow-derived murine CD11c+CD4-CD8alpha- dendritic cell function. J Gerontol A Biol Sci Med Sci 2006, 61:1039-1047.

11. Agrawal A, Agrawal S, Cao JN, Su H, Osann K, Gupta S: Altered innate immune functioning of dendritic cells in elderly humans: a role of phosphoinositide 3-kinase-signaling pathway. J Immunol 2007, 178:6912-6922.

12. Agrawal A, Agrawal S, Tay J, Gupta S: Biology of dendritic cells in aging. J Clin Immunol 2008, 28:14-20.

13. Pereira LF, de Souza AP, Borges TJ, Bonorino C: Impaired in vivo CD4+ T cell expansion and differentiation in aged mice is not solely due to T cell defects: decreased stimulation by aged dendritic cells. Mech Ageing Dev 2011, 132:187-194.

14. Li G, Smithey MJ, Rudd BD, Nikolich-Zugich J: Age-associated alterations in CD8alpha+ dendritic cells impair CD8 T-cell expansion in response to an intracellular bacterium. Aging Cell 2012, 11:968-977.

15. Wong C, Goldstein DR: Impact of aging on antigen presentation cell function of dendritic cells. Curr Opin Immunol 2013, 25:535-541.

16. Gupta S: Role of dendritic cells in innate and adaptive immune response in human aging. Exp Gerontol 2013, 54:47-52.

17. Stojic-Vukanic Z, Bufan B, Arsenovic-Ranin N, Kosec D, Pilipovic I, Perisic Nanut M, Leposavic G: Aging affects AO rat splenic conventional dendritic cell subset composition, cytokine synthesis and T-helper polarizing capacity. Biogerontology 2013, 14:443-459.

18. Fournie GJ, Cautain B, Xystrakis E, Damoiseaux J, Mas M, Lagrange D Bernard I, Subra JF, Pelletier L, Druet P, Saoudi A: Cellular and genetic factors involved in the difference between Brown Norway and Lewis rats to develop respectively type- 2 and type- 1 immunemediated diseases. Immunol Rev 2001, 184:145-160.

19. Markovic M, Miljkovic D, Momcilovic M, Popadic D, Miljkovic Z, Savic E, Ramic Z, Mostarica Stojkovic M: Strain difference in susceptibility to experimental autoimmune encephalomyelitis in rats correlates with $\mathrm{T}(\mathrm{H}) 1$ and $\mathrm{T}(\mathrm{H}) 17$-inducing cytokine profiles. Mol Immunol 2009, 47:141-146.

20. Hubert FX, Voisine C, Louvet C, Heslan JM, Ouabed A, Heslan M, Josien R: Differential pattern recognition receptor expression but stereotyped responsiveness in rat spleen dendritic cell subsets. J Immunol 2006, 177:1007-1016.

21. Pinchuk LM, Filipov NM: Differential effects of age on circulating and splenic leukocyte populations in C57BL/6 and BALB/c male mice. Immun Ageing 2008, 5:1. doi: 10.1186/1742-4933-5-1.

22. Lukic ML, Mensah-Brown E, Galadari S, Shahin A: Lack of apoptosis of infiltrating cells as the mechanism of high susceptibility to EAE in DA rats. Dev Immunol 2001, 8:193-200.

23. Popov A, Mirkov I, Miljkovic D, Belij S, Zolotarevski L, Kataranovski D, Kataranovski M: Contact allergic response to dinitrochlorobenzene (DNCB) in rats: insight from sensitization phase. Immunobiology 2011, 216:763-770.

24. Pinto LA, Galvao Castro B, Soares MB, Grassi MF: An Evaluation of the Spontaneous Proliferation of Peripheral Blood Mononuclear Cells in HTLV-1-Infected Individuals Using Flow Cytometry. ISRN Oncol 2011, 2011:326719.

25. Kamath AB, Nagarkatti PS, Nagarkatti M: Characterization of phenotypic alterations induced by 2,3,7,8-tetrachlorodibenzo-p-dioxin on thymocytes in vivo and its effect on apoptosis. Toxicol Appl Pharmacol 1998, 150:117-124. 
26. Eissler R, Schmaderer C, Rusai K, Kuhne L, Sollinger D, Lahmer T, Witzke O, Lutz J, Heemann U, Baumann M: Hypertension augments cardiac Toll-like receptor 4 expression and activity. Hypertens Res 2011, 34:551-558.

27. Vremec D, O’Keeffe M, Wilson A, Ferrero I, Koch U, Radtke F, Scott B, Hertzog P, Villadangos J, Shortman K: Factors determining the spontaneous activation of splenic dendritic cells in culture. Innate Immun 2011, 17:338-352.

28. Popma SH, Krasinskas AM, McLean AD, Szeto WY, Kreisel D, Moore JS, Rosengard BR: Immune monitoring in xenotransplantation: the multiparameter flow cytometric mixed lymphocyte culture assay. Cytometry 2000, 42:277-283.

29. Wilke CM, Wang L, Wei S, Kryczek I, Huang E, Kao J, Lin Y, Fang J, Zou W: Endogenous interleukin-10 constrains Th17 cells in patients with inflammatory bowel disease. J Transl Med 2011, 9:217.

30. Corsetti PP, de Almeida LA, Carvalho NB, Azevedo V, Silva TM, Teixeira HC, Faria AC, Oliveira SC: Lack of endogenous IL-10 enhances production of proinflammatory cytokines and leads to Brucella abortus clearance in mice. PLoS One 2013, 8:e74729.

31. Niedbala W, Wei XQ, Campbell C, Thomson D, Komai-Koma M, Liew FY: Nitric oxide preferentially induces type $1 \mathrm{~T}$ cell differentiation by selectively up-regulating IL-12 receptor beta 2 expression via cGMP. Proc Natl Acad Sci USA 2002, 99:16186-16191.

32. Agrawal A, Agrawal S, Gupta S: Dendritic cells in human aging. Exp Gerontol 2007, 42:421-426.

33. Panda A, Qian F, Mohanty S, van Duin D, Newman FK, Zhang L Chen S, Towle V, Belshe RB, Fikrig E, Allore HG, Montgomery RR, Shaw AC: Age-associated decrease in TLR function in primary human dendritic cells predicts influenza vaccine response. J Immunol 2010, 184:2518-2527.

34. Guha M, Mackman N: The PI3K-Akt pathway limits LPS activation of signaling pathways and expression of inflammatory mediators in human monocytic cells. J Biol Chem 2002, 277:32124-32132.

35. Shaw AC, Panda A, Joshi SR, Qian F, Allore HG, Montgomery RR: Dysregulation of human Toll-like receptor function in aging. Ageing Res Rev 2011, 10:346-353.

36. Corinti S, Albanesi C, la Sala A, Pastore S, Girolomoni G: Regulatory activity of autocrine IL-10 on dendritic cell functions. J Immunol 2001, 166:4312-4318.

37. Morrison RS, 3rd, Cruse JM, Wang H, Lewis RE: Dendritic cell differentiation and proliferation: enhancement by tumor necrosis factor-alpha. Exp Mol Pathol 2003, 75:228237.

38. Slobodin G, Kessel A, Peri R, Zaigraikin N, Rozenbaum M, Rosner I, Toubi E: Etanercept impairs maturation of human monocyte-derived dendritic cells by inhibiting the autocrine TNFalpha-mediated signaling. Inflammation 2009, 32:146-150.

39. You J, Dong H, Mann ER, Knight SC, Yaqoob P: Ageing impairs the T cell response to dendritic cells. Immunobiology 2013, 218:1077-1084.

40. Haruna H, Inaba M, Inaba K, Taketani S, Sugiura K, Fukuba Y, Doi H, Toki J, Tokunaga $\mathrm{R}$, Ikehara S. Abnormalities of B cells and dendritic cells in SAMP1 mice. Eur J Immunol, 1995, 25:1319-1325

41. Cannizzo ES, Clement CC, Morozova K, Valdor R, Kaushik S, Almeida L, Follo C, Sahu R, Cuervo AM, Macian F, Santambrogio L: Age-related oxidative stress compromises endosomal proteostasis. Cell Rep 2012, 2:136-149. 
42. Qi H, Denning TL, Soong L: Differential induction of interleukin-10 and interleukin-12 in dendritic cells by microbial toll-like receptor activators and skewing of T-cell cytokine profiles. Infect Immun 2003, 71:3337-3342.

43. de Waal Malefyt R, Yssel H, de Vries JE: Direct effects of IL-10 on subsets of human CD4+ $T$ cell clones and resting T cells. Specific inhibition of IL-2 production and proliferation. J Immunol 1993, 150:4754-4765.

44. Mosmann TR, Sad S: The expanding universe of T-cell subsets: Th1, Th2 and more. Immunol Today 1996, 17:138-146.

45. Lalani I, Bhol K, Ahmed AR: Interleukin-10: biology, role in inflammation and autoimmunity. Ann Allergy Asthma Immunol 1997, 79:469-483.

46. Diehl S, Rincon M: The two faces of IL-6 on Th1/Th2 differentiation. Mol Immunol 2002, 39: 531-536.

47. Oppmann B, Lesley R, Blom B, Timans JC, Xu Y, Hunte B Hunte B, Vega F, Yu N, Wang J, Singh K, Zonin F, Vaisberg E, Churakova T, Liu M, Gorman D, Wagner J, Zurawski S, Liu Y, Abrams JS, Moore KW, Rennick D, de Waal-Malefyt R, Hannum C, Bazan JF, Kastelein RA: Novel p19 protein engages IL-12p40 to form a cytokine, IL-23, with biological activities similar as well as distinct from IL-12. Immunity 2000, 13:715-725.

48. McGeachy MJ, Cua DJ: Th17 cell differentiation: the long and winding road. Immunity 2008, 28:445-453.

49. Torchinsky MB, Blander JM: T helper 17 cells: discovery, function, and physiological trigger. Cell Mol Life Sci 2010, 67:1407-1421.

50. Qu X, Liu X, Cheng K, Zhao RC: Mesenchymal stem cells inhibit Th17 cell differentiation by IL-10 secretion. Exp Hematol 2012, 40:761-770.

51. Kallen B, Nilsson O: Age as a factor determining susceptibility for experimental autoimmune encephalomyelitis in the rat. Int Arch Allergy Appl Immunol 1989, 90:16-19.

52. Ludowyk PA, Hughes W, Hugh A, Willenborg DO, Rockett KA, Parish CR: Astrocytic hypertrophy: an important pathological feature of chronic experimental autoimmune encephalitis in aged rats. J Neuroimmunol 1993, 48:121-134.

53. Ditamo Y, Degano AL, Maccio DR, Pistoresi-Palencia MC, Roth GA: Age-related changes in the development of experimental autoimmune encephalomyelitis. Immunol Cell Biol 2005, 83:75-82.

\title{
STARENJE SMANJUJE ENDOCITOZNU SPOSOBNOST DENDRITSKIH ĆELIJA SLEZINE PACOVA DARK AGOUTI SOJA I MENJA NJIHOV ODGOVOR NA STIMULACIJU TLR4
}

\author{
BUFAN Biljana, STOJIĆ-VUKANIĆ Zorica, DJIKIĆ Jasmina, KOSEC Duško, \\ PILIPOVIĆ Ivan, NACKA-ALEKSIĆ Mirjana, ARSENOVIĆ-RANIN Nevena, \\ LEPOSAVIĆ Gordana
}

Istraživanja su bazirana na podacima: 1) da je zastupljenost različitih subpopulacija slezinskih dendritskih ćelija (DC) sojno specifična i prediktivna za razvoj autoimunskih bolesti; 2) da starenje menja endocitozni, alostimulatorni i polarizacioni kapac- 
itet slezinskih OX62+ DC Albino Oxford pacova (relativno rezistentni na indukciju Th1/Th17-posredovanih autoimunskih bolesti) i 3) da postoje sojne specifičnosti u promenama mišijih DC tokom starenja. Cilj istraživanja je bio da se utvrdi da li postoje sojne specifičnosti u starenjem uslovljenim promenama DC pacova. Shodno tome, ispitivan je uticaj starenja na konvencionalne OX62+ DC Dark Agouti (DA) pacova (podložni razvoju Th1/Th17-posredovanih autoimunskih bolesti). Pokazana je predominacija CD4- ćelija u populaciji OX62+ DC kod životinja uzrasta 3 meseca (mlade), što je prediktivno za veću osetljivost na indukciju Th1/Th17-posredovanih bolesti. U skladu sa tim, lipopolisaharidom (LPS) stimulisane DC mladih pacova su indukovale Th1 polarizaciju u ko-kulturama sa alogenim CD4+ T ćelijama, najverovatnije, usled povećane ekspresije gena zaTNF- $\alpha$ i iNOS. U poređenju sa OX62+ DC mladih životinja, ove ćelije pacova uzrasta 26 meseci (stari) su pokazale smanjenu: 1) sposobnost endocitoze; 2) sposobnost sazrevanja u odgovoru na LPS in vitro (manju površinsku ekspresiju MHC II, CD86 i CD40), što je bilo u skladu sa njihovom većom produkcijom IL-10 i 3) alostimulatornu sposobnost i gubitak Th1 polarizacionog kapaciteta u ko-kulturi sa CD4+ ćelijama, najverovatnije usled veće produkcije IL-10 i nishodne regulacije ekspresije CD40 u odgovoru na LPS. U celini, rezultati sugerišu da starenje utiče na sposobnost pacova DA soja da razviju efikasan Th1 imunski odgovor i posledično bolesti posredovane Th1/Th17 tipom imunskog odgovora. 